Georgia State University

ScholarWorks @ Georgia State University

4-2013

\title{
When Older Adult Substance Abuse Affects Others: What Helps and What Doesn't?
}

Jan Ligon

Georgia State University, jligon@gsu.edu

Follow this and additional works at: https://scholarworks.gsu.edu/ssw_facpub

Part of the Social Work Commons

\section{Recommended Citation}

Ligon, Jan, "When Older Adult Substance Abuse Affects Others: What Helps and What Doesn't?" (2013). SW Publications. 56.

https://scholarworks.gsu.edu/ssw_facpub/56

This Article is brought to you for free and open access by the School of Social Work at ScholarWorks @ Georgia State University. It has been accepted for inclusion in SW Publications by an authorized administrator of ScholarWorks@ Georgia State University. For more information, please contact scholarworks@gsu.edu. 
When Older Adult Substance Abuse Affects Others: What Helps and What Doesn't?

Jan Ligon, PhD, LCSW

Georgia State University

This is an Author's Original Manuscript of an article whose final and definitive form, the Version of Record, has been published in the Journal of Social Work Practice in the Addictions, 13 (223226), 2013) CTaylor \& Francis, available online at: http://www.tandfonline.com/, DOI 10.1080/1533256X.2013.784686.

The abuse of alcohol and other drugs in the older adult population, which includes the aging "baby boomers," is escalating. It is anticipated that the need for treatment will grow to 4.4 million older adults by 2020 (Dowling, Weiss, \& Condon, 2008). The treatment admissions rate for adults over 50 doubled from 1992 to 2008, while the percentage of females admitted to treatment has increased from $18 \%$ to $25 \%$ during this period (SAMHSA, 2010). When compared to previous reports, older adults seeking treatment are less likely to be married or employed (SAMHSA, 2010).

The relationship between substance abuse and the aging process is not well understood and the literature regarding effective treatment interventions is limited (Cummings, Bride, \& Rawlins-Shaw, 2006). Even less is known about how substance abuse affects other people. This Endpage focuses on evidence based models that address "concerned significant others" or CSOs (Meyers, Roozen, \& Smith, 2011). CSOs are the other people in the person's life who are impacted by having a person with a substance abuse problem in the family. CSOs include spouses, partners, parents, grandparents, children, siblings, and others. The number of CSOs far 
exceeds the number of substance abusers. However, there is scant mention in the existing literature of this population and even less about what can help. This very large group of people has been referred to as the 'silent majority' in the addiction prevention, treatment, and recovery literature (Ligon, 2005).

While all of the intervention resources target the people who have a substance abuse problem (ONDCP, 2011), Gruber and Taylor (2006) note four compelling reasons for taking a family perspective on substance abuse: "(1) It occurs in families, (2) It harms families, (3) families both participate in and can perpetuate active addiction, and (4) families are a potential treatment and recovery resource" (p. 3). How to engage and connect with families affected by older adult substance abuse can be challenging and is likely to require some rethinking about the notion of "helping" this population.

In the past, families of substance abusers have been viewed as being codependent people, who are a part of a family disease, where each family member assumes defined roles. A manual published by the Center for Substance Abuse Treatment (2004) on helping families includes a section about codependency, but then goes on to note that scientific inquiry into the usefulness of the label is largely nonexistent. Concerning the use of family role labels, such as mascot and enabler, Vernig (2011) determined that there are more problems associated with the use of these labels than clinical benefit. There is also strong disagreement about the use of a 'family disease' view in working with those affected by substance abuse. Simply stated, families do not believe the term to be true (ADAW, 2006).

With growing concerns about the lack of usefulness for these traditional views, there has been an encouraging shift in approaches with CSOs in both the U.S. and the U.K. One example, Community Reinforcement Approach and Family Therapy (CRAFT), is an evidence-based 
model that uses strategies and goals to support desired changes (Meyers, Roozen, \& Smith, 2011). Developed in the U.K., the 5 Step Method (Copello et al., 2010) views CSOs as simply everyday people who are coping with difficult circumstances in their families. The authors are careful to avoid a family disease view or to blame family members for having responsibility for their loved ones addiction.

Two additional approaches, although not evidence-based, would fall under the category of 'promising' in the Curtis (1996) research hierarchy. Six Skills for Families Affected by Substance Abuse (Ligon, 2004) is a tool for use in learning skills related to clarification of roles and boundaries, limit setting, and goal development. Denning (2010) applies a harm reduction approach with CSOs, in order to facilitate changes in incremental steps, through understanding, and by providing support for each CSO individually.

Finally, Al-Anon, a derivative of the AA 12-Step model, provides support through selfhelp groups that are widely available in many communities. While these groups may be helpful to some, others will be challenged by the program's approach, which conveys to families that they are powerless over their loved ones addiction and to avoid efforts to change the addicted family members. To the contrary, CSOs are not powerless and can play a significant role in encouraging their addicted family member to enter treatment (Harris, 2010; Roozen, de Waart, \& van der Kroft).

Having an older adult with a substance abuse problem in the family can be very difficult and challenging to CSOs. Families are likely to experience feelings of anger, fear, frustration, and embarrassment (Denning, 2010), while others may justify the problem as simply a part of the aging process (Briggs et al, 2011). 
Although it is very apparent that more research is needed and that the level of services and funding to help CSOs is woefully inadequate, there is much that can be done now, based on what we do know. First, providers of services can consider changing their approach with families and avoid the use of simplistic terms that simply do not capture the complexity of the problem. Indeed, it is likely that our approach to CSOs matters more than the content of any particular intervention or model. Second, we can infuse content on CSOs in articles, books, websites, and other outlets so that we are able to reach more CSOs in our communities. Finally, we can avoid the trap of applying existing family models that we know and find familiar, including those that label and pathologize families. These approaches should be replaced with others that are evidence based, while we continue to build our knowledge of how we can more effectively help the many people who live in families where they are affected by an older adult who has a substance abuse problem.

Author Information: Jan Ligon, $\mathrm{PhD}, \mathrm{LCSW}$ is an Associate Professor of Social Work at Georgia State University, Atlanta, GA, USA. E-Mail: jligon@gsu.edu 


\section{References}

Alcoholism and Drug Abuse Weekly (ADAW, 2006). Public opinion poll shows deep-seated conflict about addiction as a disease, Volume 13 (33), August 21, 2006

Briggs, W.P., Magnus, V.A., Lassiter, P., Patterson, A., \& Smith, L. (2011). Substance use, misuse, and abuse among older adults: Implications for clinical mental health counselors. Journal of Mental Health Counseling, 33(2), 112-127.

Center for Substance Abuse Treatment (2004). Substance abuse treatment and family therapy. Rockville, Maryland, Substance Abuse and Mental Health Services Administration.

Copello, A., Templeton, L, Orford, J., \& Vellman. (2010) The 5-step method: Principles and practice. Drugs: education, prevention, and policy, 17, 86-99.

Cummings, S. Bride, B., and Rawlins-Shaw, A. (2006). Alcohol abuse treatment for older adults: A review of recent empirical research. Journal of Evidence-Based Social Work, 3, 79-99.

Curtis, G. C. (1996). The scientific evaluation of new claims. Research on Social Work Practice, $6(1), 117-121$.

Denning, P. (2010). Harm reduction therapy with families and friends of people with drug problems. Journal of Clinical Psychology in Session, 64(2), 164-174.

Dowling S., Weiss, R. B., \& Condon, T. P. (2008). Drugs of abuse and the aging brain. Neuropsychopharmacology, 33, 209-218

Gruber, K.J., \& Taylor, M. F. (2006). A family perspective for substance abuse: Implications from the literature. Journal of Social Work Practice in the Addictions, 6 (1/2), 1-29. Harris, P. (2010). The concerned other: How to change problematic drug and alcohol users through their family members. Lyme Regis, UK: Russell. 
Ligon, J. (2004). Six “Ss” for families affected by substance abuse: Family skills for survival and change. Journal of Family Psychotherapy (15), 95-99.

Ligon, J. (2005). Families and significant others: the silent majority in addiction treatment and recovery. NAADAC News, National Association for Addiction Professionals, 15 (4).

Meyers, R. J., Roozen, H. G., \& Smith, J. E. (2011). The Community reinforcement approach:

An update of the evidence. Alcohol Research \& Health, 33(4), 380-388.

Office of National Drug Control Policy (ONDCP, 2011). National drug control budget, FY 2012. Retrieved from: http://www.whitehouse.gov/sites/default/files/ondcp/policy-andresearch/fy12highlight_exec_sum.pdf

Roozen, H. G. de Waart, R., \& Petra van der Kroft, P (2010). Community reinforcement and family training: an effective option to engage treatment-resistant substance-abusing individuals in treatment. Addiction, 105, 1729-1738

SAMHSA: Substance Abuse and Mental Health Services Administration (2010). Office of Applied Studies. . The TEDS report: Sociodemographic characteristics of substance abuse treatment admissions aged 50 or older: 1992 to 2008. Rockville, MD. Retrieved from: http://www.oas.samhsa.gov/2k10/240/240OlderAdm2k10Web.pdf

Vernig, P. K. (2011.). Family roles in homes with alcohol-dependent parents: Am evidencebased review. Substance Use and Misuse, 46, 535-542. 